\title{
PENGEMBANGAN PERANGKAT PEMBELAJARAN IPASMPBERBASIS PROBLEM BASED LEARNING PADA MATERI GETARAN DAN GELOMBANG
}

\author{
Heru Edi Kurniawan \\ Program Studi Pendidikan Fisika, FKIP, Universitas Sebelas Maret Surakarta \\ Email : heruedi@gmail.com
}

\begin{abstract}
Abstrak
Penelitian dan pengembangan ini bertujuan mengembangkan perangkat pembelajaran IPA Fisika berbasis problem based learning untuk siswa SMP kelas VIII yang berkualitas dan mengetahui pencapaian hasil belajar siswa setelah mengikuti proses pembelajaran. Penelitian ini menggunakan metode Research and Development (R\&D) dengan mengacu pada model Borg \& Gall yang dimodifikasi. Sampel pengembangan meliputi sampel validasi produk sejumlah 9 validator, sampel uji coba terbatas sejumlah 8 siswa, dan sampel uji coba diperluas sejumlah 31 siswa. Instrumen yang digunakan adalah lembar validasi silabus, RPP, penilaian kognitif berupa soal tes hasil belajar (pretest-posttest), psikomotorik, afektif, lembar observasi sekolah, keterlaksanaan pembelajaran, karakteristik siswa, dan angket respon siswa. Uji coba diperluas dengan one group pretest-posttest design. Data hasil belajar kognitif dianalisis dengan uji $\mathrm{t}$ dua sampel berpasangan dengan menggunakan program SPSS Statistik 18, sedangkan data hasil belajar psikomotorik dan afektif siswa dianalisis dengan melihat rata-rata pencapaian setiap aspek penilaian. Penelitian dan pengembangan yang telah dilaksanakan memberikan kesimpulan: (1) pengembangan perangkat pembelajaran IPA Fisika SMP berbasis problem based learning terintegrasi pendidikan karakter dapat dilakukan menggunakan metode Research and Development oleh Borg \& Gall yang dimodifikasi dengan membatasi langkah penelitian yang dapat menghasilkan suatu produk yang divalidasi dan diuji coba, (2) kualitas produk perangkat pembelajaran yang dikembangkan mendapatkan nilai dengan kategori sangat baik sehingga layak digunakan, dan (3) pencapaian hasil belajar kognitif siswa setelah mengikuti proses pembelajaran mengalami peningkatan, aspek indikator psikomotor yang tinggi adalah mengecek alat bahan di laboratorium dan membawa perlengkapan belajar.
\end{abstract}

Kata Kunci: pengembangan perangkat pembelajaran, problem based learning, hasil belajar

\section{Pendahuluan}

Pendidikan adalah usaha sadar dan terencana untuk mewujudkan suasana belajar dan proses pembelajaran agar peserta didik secara aktif mengembangkan potensi dirinya untuk memiliki kekuatan spiritual keagamaan, pengendalian diri, kepribadian, kecerdasan, akhlak mulia, serta keterampilan yang diperlukan dirinya, masyarakat, bangsa dan negara, hal ini tertuang dalam Pasal 1, Ayat (1) UU RI No 20 Tahun 2003. Dalam Undangundang tersebut, pendidikan nasional berfungsi mengembangkan kemampuan dan membentuk watak serta peradaban bangsa yang bermartabat dalam rangka mencerdaskan kehidupan bangsa, bertujuan untuk berkembangnya potensi peserta didik agar menjadi manusia yang beriman dan bertakwa kepada Tuhan Yang Maha Esa, berakhlak mulia, sehat, berilmu, cakap, kreatif, mandiri, dan menjadi warga negara yang demokratis serta bertanggung jawab.

Terdapat banyak masalah pada sistem pendidikan, baik dari subjek maupun objek dari pendidikan itu sendiri. Subjek yang dimaksud adalah pelaku pendidikan, yaitu guru, dan objeknya yaitu siswa. Sebagai subjek, guru memiliki peranan yang sangat penting dalam kemajuan peradaban bangsa. Karena begitu pentingnya peranan guru, pemerintah mengatur dalam UU RI No. 14 tahun 2005 tentang guru dan dosen pada pasal 7 ayat 1. Pada UU tersebut dinyatakan bahwa setiap tenaga kependidikan merupakan pekerjaan khusus yang melandasi pekerjaan dengan prinsip 
profesional. Sehingga guru mempunyai kewajiban untuk melaksanakan tugas dengan penuh tanggung jawab dan pengabdian, meningkatkan kemampuan profesional sesuai dengan tuntutan perkembangan ilmu pengetahuan dan teknologi serta pembangunan bangsa.

Guru dalam melaksanakan tugas profesional, salah satu kewajibannya adalah menjunjung tinggi perundang-undangan, hukum dan kode etik guru serta nilai-nilai agama dan etika. Realita yang terjadi pada tataran subjek saat ini ternyata masih banyak guru yang belum menyadari kewajibannya tersebut, yaitu masih banyak guru yang perbuatan amoral dan juga tersandung kasus hukum, mulai tindak asusila, tindak kriminal, peredaran narkoba dan sebagainya.

Guru merupakan publik figur bagi para peserta didik, karena para peserta didik tidak hanya belajar dari yang dikatakan oleh guru, namun mereka juga belajar dari totalitas kepribadian guru. Kepribadian guru merupakan sikap kepribadian yang mantap, sehingga mampu menjadi sumber intensifikasi bagi objek, dalam hal ini berarti guru harus memiliki kepribadian yang pantas diteladani dan mampu melaksanakan kepemimpinan, seperti yang dikemukakan oleh Ki Hajar Dewantara, yaitu "Ing Ngarsa Sung Tuladha, Ing Madya Mangun Karsa, Tut Wuri Handayani”.

Dalam Permendiknas nomor 41 tahun 2007 dan UU RI No. 20 tahun 2003 Bab IV pasal 14 ayat 1 dan 2 adalah kewajibannya dalam merencanakan pembelajaran, melaksanakan proses pembelajaran yang bermutu, serta menilai dan mengevaluasi hasil pembelajaran. Pelaksanaan pembelajaran yang bermutu tentu terkait dengan kesiapan guru, pemilihan metode, terkait dengan ketersediaan media, dan kesiapan siswa.

Salah satu kesulitan guru dalam mengimplementasikan Permendiknas nomor 41 tahun 2007 adalah pengembangan perangkat pembelajaran dan pemilihan model pembelajaran yang aktif, inovatif, kreatif, efektif, dan menyenangkan. Realita saat ini ditemukan bahwa masih ada silabus dan RPP yang disusun dengan cara menyalin dari pihak lain, misalnya internet atau kawan. Pembuatanya belum sesuai dengan standar dari BNSP dan pakar pendidikan.
Mulyasa (2007) menjelaskan ada beberapa faktor yang menyebabkan rendahnya profesionalitas guru, diantaranya: (1) masih banyak guru yang tidak menekuni profesinya secara utuh; (2) belum adanya standar profesionalitas guru; (3) banyak guru yang tidak patuh terhadap etika profesinya; (4) kurangnya motivasi guru dalam meningkatkan kualitasnya.

Realita lain yang ditemukan, pendidikan belumlah optimal dan secara merata mencerdaskan kehidupan bangsa dan sekaligus mengembangkan potensi keimanan dan ketakwaan kepada Tuhan Yang Maha Esa, berakhlak mulia, sehat, berilmu, cakap, kreatif, mandiri, dan bertanggung jawab. Menurut Kesuma (2011) kondisi generasi penerus bangsa saat ini mungkin dapat menggambarkan realita bangsa yaitu kondisi moral generasi penerus bangsa yang rusak atau hancur. Hal ini ditandai dengan maraknya hubungan di luar nikah di kalangan remaja (generasi muda), peredaran narkoba, tawuran pelajar, peredaran foto dan video porno, dan sebagainya.

Tujuan yang ingin dicapai dalam penelitian ini adalah untuk mengetahui (1) tahapan-tahapan dalam mengembangkan perangkat pembelajaran IPA Fisika SMP berbasis problem based learning terintegrasi pendidikan karakter siswa SMP kelas VIII; (2) kualitas perangkat pembelajaran IPA Fisika SMP berbasis problem based learning terintegrasi pendidikan karakter berdasarkan penilaian ahli, guru IPA Fisika SMP, dan teman sejawat; (3) pencapaian hasil belajar siswa setelah menggunakan perangkat pembelajaran IPA Fisika SMP berbasis problem based learning

\section{Metode Penelitian}

Metode penelitian ini adalah Research and Development atau penelitian dan pengembangan yang mengadaptasi model Borg \& Gall dengan mengambil 7 tahapan pengembangan: (1) Research and information collecting (melakukan pengumpulan informasi, termasuk kajian pustaka, pengamatan kelas, membuat kerangka kerja penelitian); (2) Planning (melakukan perancangan, merumuskan tujuan penelitian, memperkirakan dana dan waktu yang diperlukan, prosedur kerja 
penelitian); (3) Develop preliminary form of product (mengembangkan bentuk produk awal atau perancangan draf awal produk dan memvalidasi produk); (4) Preliminary field testing (melakukan uji coba terbatas); (5) Main product revision (melakukan revisi terhadap produk utama); (6) Main field testing (melakukan uji coba diperluas); dan (7) Operational product revision (melakukan revisi terhadap uji diperluas). Proses penelitian berlangsung sejak November 2012 sampai Juni 2013

Teknik pengumpulan data dalam penelitian ini menggunakan: (1) metode observasi dan wawancara untuk analisis kebutuhan siswa, (2) validasi produk untuk mendapatkan penilaian serta saran terhadap desain produk awal pengembangan, (3) tes hasil belajar untuk melihat peningkatan pemahaman siswa sebelum dan setelah proses pembelajaran. Tes diberikan dua kali yaitu pretest dan posttestt.

Pengembangan produk awal meliputi pengembangan draft perangkat pembelajaran meliputi: silabus, rencana pelaksanaan pembelajaran (RPP), media pembelajaran, kisikisi penilaian, lembar penilaian produk kognitif, kunci jawaban, petunjuk penilaian, rubrik penilaian psikomotorik, lembar penilaian psikomotorik, rubrik penilaian afektif, lembar penilaian afektif, dan modul siswa berbasis problem based learning.

Tahapan validasi produk awal dalam penelitian pengembangan ini melibatkan 3 orang pakar pendidikan Fisika yang memiliki latar belakang master dan doktor pendidikan, 3 orang teman sejawat, dan 3 orang guru Fisika SMP. Hasil validasi diujicobakan secara terbatas pada 8 siswa kelas VIII SMP IT Nur Hidayah Surakarta dilanjutkan dengan uji coba lebih luas dengan jumlah responden sebanyak 31 siswa setelah melalui tahap revisi produk perangkat pembelajaran.

Instrumen dalam penelitian adalah lembar observasi sekolah, lembar observasi karakteristik siswa, lembar validasi perangkat pembelajaran, lembar observasi keterlaksanaan pembelajaran, lembar respon siswa terhadap perangkat pembelajaran, lembar penilaian afektif (karakter) siswa, lembar observasi psikomotorik, lembar instrumen soal (evaluasi hasil belajar).
Data yang dikumpulkan dalam penelitian ini adalah sebagai berikut: (1) data hasil validasi ahli berupa penilaian terhadap silabus, RPP, penilaian produk kognitif, penilaian psikomotorik, penilaian afektif, media pembelajaran, dan modul. Teknik pengumpulan data menggunakan lembar validasi perangkat pembelajaran yang ditujukan kepada ahli materi dan media pendidikan, guru IPA Fisika SMP serta teman sejawat, (2) data hasil uji coba terbatas dan uji coba diperluas perangkat pembelajaran yang berupa data keterlaksanaan pembelajaran yang diperoleh dari pengamat dan data hasil belajar siswa yang diperoleh dari pretest dan posttestt, serta data hasil penilaian psikomotorik dan afektif, (3) data angket respons siswa terhadap pembelajaran.

Uji efektifitas penelitian ini menggunakan one group pretest-posttest design. Siswa diberikan pretest sebelum mengikuti proses pembelajaran. Setelah seluruh rangkaian pembelajaran selesai maka dilihat peningkatan hasil belajar siswa dengan membandingkan antara nilai pretest dan posttest. Penilaian terhadap pencapaian keterampilan psikomotorik dan afektif siswa dilakukan selama proses pembelajaran dengan kolaborasi antara observer dan guru pengajar.

Penilaian akhir hasil validasi perangkat pembelajaran di adaptasi dan dikembangkan dari Widoyoko cit Triyanto (2010) dengan menabulasi semua data yang diperoleh dari pada validator ahli, menghitung skor total ratarata dari setiap komponen, dan mengubah skor rata-rata menjadi nilai dengan kriteria. Keterlaksanaan pembelajaran dan respons siswa diadaptasi dan dikembangkan dari Triyanto (2010), hasil pretest dan posttest siswa dianalisis normalitas dengan uji KolmogorovSmirnov dan homogenitas dengan uji Levene's serta uji $\mathrm{t}$ dengan dua sampel berpasangan untuk mengetahui signifikansi dari hasil pretest-postest. Penilaian akhir untuk pencapaian psikomotorik dan afektif di adaptasi dan dikembangkan dari Depdiknas (2007) dan Kemendiknas (2010). Hasil psikomotorik dan afektif tiap pertemuan diketahui dengan melakukan rata-rata hasil tiap aspek. Semua uji dilakukan menggunakan software IBM SPSS Statistics 18. 


\section{http://e-journal.ikippgrimadiun.ac.id/index.php/JPFK}

\section{Hasil Penelitian Pengembangan dan Pembahasan}

\section{Hasil Penelitian dan Pengembangan}

1. Hasil Tahap Studi Pendahuluan

a. Studi Pustaka

Hasil studi pustaka merupakan hasil kajian konsep-konsep atau teori-teori dan hasilhasil penelitian terdahulu dan hasil penguasaan materi pada ujian nasional 2012 se-kota Surakarta, serta analisis SK-KD IPA Fisika SMP yang mengacu pada standar isi (Permendiknas Nomor 22 Tahun 2006).

\section{b. Survei Lapangan}

Observasi yang dilakukan memberikan hasil: 1) Perangkat pembelajaran yang dimiliki oleh masing-masing guru sekolah tersebut cukup lengkap, terdiri dari silabus, RPP, lembar evaluasi, dan bahan ajar; 2) Perangkat pembelajaran tidak saling terpadu dan tidak mendukung pembelajaran yang kreatif, inovatif, dan kontekstual, serta belum optimal dalam mengintegrasikannya dengan pendidikan karakter; 3) Sarana dan prasarana sekolah cukup lengkap dengan adanya laboraotorium IPA dan perpustakaan; 4) Kemampuan akademik dan motivasi belajar siswa masih rendah; 5) keterampilan psikomotorik, keterampilan sosial dan karakter belum terlihat. 6) Perangkat pembelajaran tidak digunakan secara optimal hanya sebagai keperluan administrasi sekolah.

c. Hasil Analisis Kebutuhan

Dengan melihat peringkat SKL minimum pada Tabel 1 di tingkatan sekolah yang mencerminkan kondisi pembelajaran di sekolah serta kebutuhan akan perangkat pembelajaran yang ideal dalam rangka meningkatkan kualitas pembelajaran, maka kebutuhan prioritas utama untuk sekolah yang cocok pada perlunya pengembangan perangkat pada materi getaran dan gelombang. Tabel 1. Ringkasan Hasil Analisis UN SMP Se kota Surakarta

\begin{tabular}{clcc}
\hline Peringkat & \multicolumn{1}{c}{ Sekolah } & $\begin{array}{c}\text { Besar penguasaan } \\
(\mathbf{\%})\end{array}$ & $\begin{array}{c}\text { Posisi } \\
\text { SKL Terendah }\end{array}$ \\
\hline 1 & SMP N 1 Surakarta & 59,52 & 1 \\
2 & SMP IT Nur Hidayah & 53,04 & 1 \\
3 & SMP N 4 Surakarta & 48,67 & 2 \\
4 & SMP N 9 Surakarta & 48,81 & 2 \\
5 & SMP BL Bintang Laut & 58,16 & 7 \\
$\ldots$ & $\ldots$ & $\ldots$ & 7 \\
\hline
\end{tabular}

\section{Hasil Tahap Perencanaan}

Berdasarkan data hasil tahap studi pendahuluan dan analisis kebutuhan, maka produk penelitian pengembangan berupa perangkat pembelajaran yang akan dikembangkan adalah: (a) SK yang akan dipilih untuk dikembangkan perangkat pembelajarannya adalah SK 6 "memahami konsep dan penerapan getaran, gelombang, dan optika dalam produk kehidupan sehari-hari". Pada kompetensi dasar 6.1 "mendeskripsikan konsep getaran dan gelombang serta parameterparameternya", (b) terdapat arahan bagi guru sebagai pengguna perangkat pembelajaran untuk mendidik dan mengembangkan karakter siswa (afektif), yaitu rasa ingin tau, gemar membaca, kerja keras, jujur, kreatif dalam pembelajaran Fisika materi getaran dan gelombang, (c) terdapat arahan bagi guru sebagai pengguna perangkat pembelajaran untuk mengembangkan kemampuan psikomotorik dan keterampilan siswa, (d) terdapat keterpaduan antar silabus, RPP, lembar evaluasi dan pengamatan, modul siswa serta berbasis problem based learning terintegrasi pendidikan karakter.

Perencanaan dan Pemilihan SK dan KD mengacu pada analisis standar isi (Permendiknas Nomor 22 Tahun 2006). Indikator pembelajaran disesuaikan dengan pencapaian KD yang diingnkan mencangkup indikator kognitif produk, kognitif proses, psikomotorik, dan afektif. Tujuan pembelajaran disesuaikan dengan Permendiknas Nomor 41 Tahun 2007 tentang standar proses. Berdasarkan tujuan pembelajaran tersebut, materi pembelajaran, karakteristik siswa, dan fasilitas yang tersedia, maka model pembelajaran yang cocok adalah Problem Based Learning (PBL) dengan metode tugas, kerja kelompok, diskusi, tanya jawab, dan 
JPFK, Vol. 2 No. 1, Maret 2016, hal 16 - 28

http://e-journal.ikippgrimadiun.ac.id/index.php/JPFK

percobaan yang berbasis masalah. Konsep materi yang diajarakan adalah getaran dan gelombang.

3. Hasil Tahap Penyusunan Draf I

a. Silabus

Desain awal silabus yang telah dikembangkan, terdapat komponen komponen: (1) nama mata pelajaran, jenjang, sekolah, kelas, dan semester dengan jelas, (2) SK yang merupakan pernyataan tentang pengetahuan, keterampilan dan sikap, 3) KD, perincian atau penjabaran lebih lanjut dari standar kompetensi, (4) materi pokok sebagai sarana pencapaian KD dan yang akan dinilai menggunakan instrumen penilaian berdasarkan indikator pencapaian hasil belajar, (5) pengalaman belajar siswa, (6) jabaran KD menjadi indikator, (7) jabaran indikator ke dalam instrumen penilaian, (8) alokasi waktu, (9) sumber atau bahan ajar, (10) komponen karakter yang terbentuk dari setiap $\mathrm{KD}$.

b. RPP

Desain awal RPP yang telah dikembangkan, terdapat komponen-komponen: (1) SK dan KD, (2) indikator pencapaian KD, (3) alokasi waktu, (4) rumusan tujuan pembelajaran, (5) materi pembelajaran, (6) metode pembelajaran, (7) langkah-langkah kegiatan pembelajaran yang mengikuti sintaks problem based learning dengan memadukan modul dan mengintegrasikan pendidikan karakter, (8) membagi setiap jam pertemuan berdasarkan pada satuan tujuan pembelajran atau sifat atau tipe materi pembelajaran, (9) sumber atau media pembelajaran, (10) teknik penilaian.

c. Modul
Desain awal modul yang telah dikembangkan terdapat komponen: (1) tujuan modul dan petunjuk belajar, (2) kompetensi yang akan dicapai, (3) informasi pendukung, (4) fenomena alam yang menjadi pemunculan masalah, (5) materi modul, (6) lembar kegiatan siswa, (7) kegiatan pralaboratorium, (8) kegiatan laboratorium, (9) kolom pendidikan karakter, (10) sumber-sumber belajar, (11) penilaian.

d. Media Pembelajaran

Media dikembangkan dengan memperhatikan beberapa aspek antara lain: (1) bahan yang disajikan agar lebih jelas maknanya bagi siswa, (2) metode pembelajaran lebih bervariasi, (3) siswa agar lebih aktif dalam melakukan beragam aktivitas, (4) pembelajaran lebih menarik, (5) mengatasi keterbatasan ruang. Media pembelajaran animasi yang menggunakan program Macromedia Flash 8.

\section{e. Perangkat Penilaian}

Desain awal perangkat penilaian yang telah dikembangkan, terdapat komponenkomponen: (1) kisi-kisi soal yang telah disesuaikan dengan indikator kognitif produk, (2) soal pilihan ganda yang mengikuti kisi-kisi soal, (3) kunci jawaban dari setiap soal pilihan ganda, (4) lembar observasi psikomotorik dan rubrik penilaiannya, (5) lembar observasi afektif (karakter) dan rubrik penilaiannya.

\section{Hasil Tahap Validasi Produk Awal}

Rerata hasil validasi terhadap produk awal oleh 9 validator disajikan pada Tabel 2 dengan skor maksimum 4.

\begin{tabular}{lcc} 
Tabel 2. Hasil Validasi & & \\
$\begin{array}{l}\text { Validator } \\
\text { Produk }\end{array}$ & Rerata & Kategori \\
\hline Silabus & & Sangat Baik \\
RPP & 4 & Sangat Baik \\
Media Pembelajaran & 4 & Sangat Baik \\
Kisi-kisi dan & 4 & Sangat Baik \\
Petunjuk Penilaian & 4 & Sangat Baik \\
$\begin{array}{l}\text { Lembar Kognitif } \\
\text { Lembar Penilaian }\end{array}$ & 4 & Sangat Baik \\
Psikomotorik & 4 & \\
Lembar Afektif & 4 & Sangat Baik \\
Modul & 4 & Sangat Baik \\
Rata-Rata & Sangat Baik \\
\hline
\end{tabular}

5. Hasil Penyusunan Draf II

Penyusunan draf II menggunakan hasil saran dan masukan dari semua validator dalam penyempurnaan produk perangkat 
JPFK, Vol. 2 No. 1, Maret 2016, hal 16 - 28

http://e-journal.ikippgrimadiun.ac.id/index.php/JPFK

pembelajaran. Saran yang tidak dipakai adalah penambahan waktu pada saat pembelajaran. Hal ini tidak dilakukan karena disesuaikan dengan standar waktu pembelajaran di sekolah yaitu 1 jam pelajaran adalah 40 menit.

6. Hasil Tahap Uji Coba a. Uji Coba Terbatas

Tanggapan yang diberikan oleh siswa pada uji coba terbatas terhadap pembelajaran menggunakan Draf II dari produk yang dikembangkan disajikan pada Tabel 3 dengan skor maksimum 4 . b. Revisi II

Revisi dilalkukan secara teknis yaitu memperbaiki tata tulis dan tata bahasa perangkat pembelajaran.
Tabel 3: Hasil Tanggapan Siswa Pada Uji Coba Terbatas

\begin{tabular}{lccc}
\multicolumn{1}{c}{ Aspek } & $\begin{array}{c}\text { Orie } \\
\text { ntasi }\end{array}$ & $\begin{array}{c}\text { Pengembangan } \\
\text { Karakter } \\
\text { Siswa }\end{array}$ & $\begin{array}{c}\text { Pengembangan } \\
\text { keterampilan } \\
\text { psikomotor }\end{array}$ \\
\hline $\begin{array}{l}\text { Tanggapan } \\
\text { Siswa }\end{array}$ & 2,94 & 3,10 & 3,073 \\
\hline Rerata & \multicolumn{3}{c}{3,04} \\
\hline Kategori & \multicolumn{3}{c}{ Baik } \\
\hline
\end{tabular}

Tanggapan yang diberikan oleh siswa pada uji coba diperluas terhadap pembelajaran menggunakan Draf II dari produk yang dikembangkan disajikan pada Tabel 4 dengan skor maksimum 4.

c. Hasil Uji Coba Diperluas

Tabel 4. Hasil Tanggapan Siswa Pada Uji Coba Terbatas

\begin{tabular}{lcc}
\multicolumn{1}{c}{ Aspek } & Orientasi & Pengembangan keterampilan psikomotor \\
\hline Tanggapan & 3,13 & 3,06 \\
Siswa & & \\
\hline Rerata & & 3,08 \\
\hline Kategori & Baik \\
\hline
\end{tabular}

Deskripsi hasil test belajar kognitif siswa disajikan pada Tabel 5. Hasil Uji prasyarat dan uji t dua sampel berpasangan untuk hasil belajar kognitif disajikan pada Tabel 6.

Tabel 5. Deskripsi Hasil Belajar Kognitif Siswa

\begin{tabular}{cccc}
\hline Jenis Test & N & Mean & Standar Deviasi \\
\hline Pretest & 31 & 42,51 & 12,46 \\
\hline Posttest & 31 & 63,32 & 11,46
\end{tabular}

Deskripsi nilai perolehan klasikal siswa yang ditunjukkan disajikan pada Tabel 7 dan untuk keterampilan psikomotor untuk setiap Tabel 8 dengan nilai maksimum 4.

karakter dan hasil test belajar psikomotor siswa

Tabel 6. Ringkasan hasil analisis pretest dan posttest

\begin{tabular}{cccc}
\hline Yang diuji & Normalitas & Homogenitas & Hasil pretest posttest \\
\hline Jenis uji & Kolmogorov-Smirnov & Levene's test & Paired Samples Test \\
\hline Signifikansi & $\begin{array}{c}\text { Pretest }=0,200 \\
\text { Posttest }=0,115\end{array}$ & 0,545 & $\begin{array}{c}\mathrm{t}_{\text {hitung }}=-12,028 \\
\mathrm{t}_{5 \%}=2,04 \text { dan } \mathrm{t}_{1 \%}=2,75 .\end{array}$ \\
\hline Keputusan & $\mathrm{H}_{0}$ diterima & $\mathrm{H}_{0}$ ditolak \\
\hline Kesimpulan & Data normal & $\mathrm{H}_{0}$ diterima & Ada perbedaan pretest dan posttest \\
\hline
\end{tabular}

Tabel 7. Deskripsi Hasil Pencapaian Psikomotorik Siswa

\begin{tabular}{cccc}
\hline Pertemuan & N & Mean & Standar Deviasi \\
\hline I & 31 & 50,90 & 4,65 \\
\hline II & 31 & 51,87 & 4,96 \\
\hline
\end{tabular}

Tabel 8. Deskripsi Hasil Pencapaian Psikomotorik Siswa

\begin{tabular}{ccc}
\hline No & Kriteria & Rerata \\
\hline 1. & Mengecek alat dan bahan & 3,58
\end{tabular}


JPFK, Vol. 2 No. 1, Maret 2016, hal 16 - 28

http://e-journal.ikippgrimadiun.ac.id/index.php/JPFK

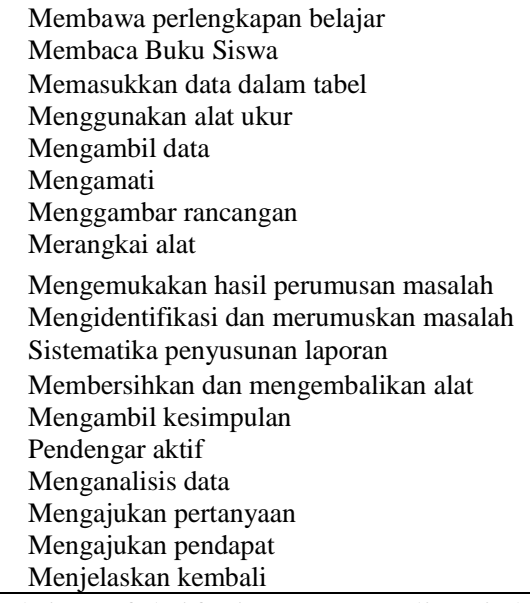

keterampilan afektif untuk setiap karakter yang

Tabel 9. Deskripsi Hasil Pencapaian Afektif Siswa

\begin{tabular}{cccc}
\hline Pertemuan & N & Mean & Standar Deviasi \\
\hline I & 31 & 16,58 & 2,67 \\
\hline II & 31 & 17,19 & 2,02 \\
\hline
\end{tabular}

Tabel 10. Analisis Keterampilan Afektif Berdasarkan Karakter

\begin{tabular}{clc}
\hline No. & \multicolumn{1}{c}{ Aspek yang diamati } & Rata-rata \\
\hline 1. & Jujur & 3,53 \\
2. & Rasa ingin tahu & 3,21 \\
3. & Disiplin & 3,03 \\
4. & Kerja Keras & 3,00 \\
5. & Kreatif & 2,24 \\
6. & Gemar Membaca & 1,87 \\
\hline
\end{tabular}

\section{Pembahasan}

\section{Tahap Studi Pendahuluan}

Kegiatan awal studi pendahuluan, yaitu studi pustaka, telah di analisis SK dan KD serta materi pembelajaran kelas VIII SMP semester I dan II (analisis kurikulum) yang diidentifikasi dari SK dan KD yang terdapat pada standar isi Permendiknas Nomor 22 Tahun 2006. Menurut Prastowo (2012) langkah analisis SK dan KD dalam tahap awal pengembangan perangkat pembelajaran sangat penting, karena bertujuan untuk menentukan kompetensi-kompetensi yang tepat, sehingga mampu membuat siswa menguasai kompetensi yang telah ditentukan.

Setelah dilakukan analisis SK dan KD, pemilihan materi pada penelitian ini didasarkan pada hasil analisis penguasaan materi ujian nasional 2011 pada Tabel 1 dengan hasil penguasaan materi paling rendah terdapat pada materi getaran dan gelombang yang terdapat di kelas VIII SMP semester II. Kakteristik siswa kelas VIII menurut teori belajar Piaget yang memandang perkembangan kognitif sebagai suatu proses anak secara aktif membangun sistem makna dan pemahaman realitas melalui pengalaman-pengalaman dan interaksi sosial. Siswa kelas VIII SMP berada pada usia lebih dari 11 tahun dengan kategori operasional formal dengan kemampuan utama berfikir abstrak dan murni simbolis dan dapat memecahkan masalah menggunakan eksperimentasi sistematis. Hal ini mendukung pelaksanaan problem based learning yang menurut Dewey (2001) membutuhkan interaksi antara stimulus dan respons antara belajar dan lingkungan. Lingkungan memberikan masukan kepada siswa berupa bantuan dan masalah kemudian sistem saraf otak berfungsi menafsirkan bantuan tersebut secara efektif sehingga masalah yang dihadapi dapat diselidiki, dinilai, dan dianalisis serta dicari pemecahanya dengan baik.

Kegiatan berikutnya dari tahap studi pendahuluan adalah survei lapangan. Hal-hal yang telah teridentifikasi dari kegiatan survei lapangan, yaitu (a) cukup lengkapnya kelengkapan sarana dan prasarana sekolah, yaitu memiliki perpustakaan, LCD Proyektor, laboratorium Fisika, dan kelengkapan alat-alat 
JPFK, Vol. 2 No. 1, Maret 2016, hal 16 - 28

\section{http://e-journal.ikippgrimadiun.ac.id/index.php/JPFK}

penunjang praktikum Fisika untuk kelas VIII sesuai amanat UU Sisdiknas No. 20 Tahun 2003 dan menurut Triyanto (2009) bahwa salah satu kekurangan penerapan pembelajaran berbasis masalah adalah persiapan belajar yang membutuhkan alat yang kompleks, untuk agar memperlancar proses pembelajaran berbasis masalah maka diperlukan sarana dan prasana yang memadai, (b) guru telah memiliki perangkat pembelajaran cukup lengkap mulai RPP, silabus, dan lembar penilaian kognitif namun belum semua guru mempunyai lembar penilaian afektif dan psikomotorik serta bahan ajar yang tetap seperti buku pegangan atau modul menurut Prastowo (2012) sangat mutlak diperlukan oleh guru, selain merupakan tuntutan, hal ini juga memiliki kontribusi besar dalam keberhasilan proses pembelajaran, (c) guru belum sepenuhnya mempunyai perangkat pembelajaran yang terintegrasi pendidikan karakter. Hal ini belum sesuai dengan yang diharapkan oleh pemerintah melalui Kemendiknas (2010), bahwa pengembangan nilai-nilai pendidikan budaya dan karakter bangsa diintegrasikan dalam setiap pokok bahasan dari setiap mata pelajaran, (d) hasil observasi karakteristik siswa yaitu kemampuan akademik beberapa materi pembelajaran IPA Fisika yang rendah yang telah dijadikan kerangka acuan dalam menyusun materi pembelajaran dan pemilihan metode pembelajaran (Trianto, 2011).

\section{Tahap Perencanaan}

Data hasil yang diperoleh pada tahap studi pendahuluan, menjadi dasar untuk menentukan perencanaan produk yang akan dikembangkan berikut spesifikasinya dan kajian-kajian yang akan muncul pada perangkat pembelajaran, kemudian kajian tersebut dijelaskan lebih terperinci dengan perencanaan pembelajaran yang dimulai dengan perumusan standar kompetensi, kompetensi dasar, indikator pembelajaran, tujuan pembelajaran, model pembelajaran, metode pembelajaran, serta analisis konsep dari kajian tersebut, sehingga produk yang dikembangkan diharapkan dapat menjadi dasar dalam merencanakan pembelajaran yang sistematis dan mengombinasikan unsur-unsur manusiawi, material, fasilitas, perlengkapan, dan prosedur yang saling mempengaruhi dalam mencapai tujuan pembelajaran (Carol dan Leslie, 2010).

\section{Tahap Penyusunan Produk Awal}

a. Pengembangan Silabus

Pengembangan silabus sesuai dengan prinsip-prinsip pengembangan silabus oleh BSNP (2006) yaitu ilmiah, relevan, sistematis, konsisten, memadai, aktual dan kontekstual, serta fleksibel. Langkah-langkah pengembangannya juga telah sesuai dengan langkah-langkah penyusunan silabus menurut Suwarna (2011).

b. Pengembangan RPP

Penyusunan RPP telah sesuai dengan prinsip-prinsip penyusunan RPP yang dikemukakan oleh Ibrahim (2003), yaitu memperhatikan perbedaan individu siswa, mendorong partisipasi aktif siswa mengembangkan budaya membaca dan menulis, memberikan umpan balik dan tindak lanjut, keterkaitan dan keterpaduan, serta menerapkan teknologi informasi dan komunikasi. Selain prinsip, langkah-langkah penyusunannya pun telah menyesuaikan BSNP (2006) dan Ibrahim (2003).

c. Pengembangan Modul

Penyusunan modul disesuaikan dengan sintaks PBL yaitu kegiatan yang mewakili masing-masing langkah (1) Orientasi siswa pada masalah pada kegiatan I: "Perhatikan Peristiwa di Bawah Ini!",

Mengorganisasikan siswa untuk belajar yaitu kegiatan II: "Sejauh Mana Pengetahuanmu", (3) Membimbing penyelidikan individu maupun kelompok yaitu kegiatan III: "Ayo Kita Lakukan!", (4) Mengembangkan dan menyajikan hasil karya yaitu kegiatan IV: "Kerja Proyek", (5) Menganalisis dan mengevaluasi proses pemecahan masalah yaitu kegiatan V: "Kamu Pasti Bisa!". Sesuai pendapat Triyanto (2009) modul merupakan panduan dalam kegiatan pembelajaran yang memuat materi pembelajaran, kegiatan penyelidikan berdasarkan konsep, kegiatan sains, informasi, dan contoh-contoh penerapan sains dalam kehidupan sehari-hari.

d. Pengembangan Media Pembelajaran

Menurut Noorina cit Fauzi (2009) media adalah suatu eksistensi manusia yang memungkinkaya mempengaruhi orang lain yang tidak mengadakan kontak langsung denganya. Kelebihan yang ada didalam media pembelajaran ini, antara lain: (a) materi yang disajikan dilengkapi dengan animasi sehingga lebih mudah dipahami, (b) menampilkan gambar-gambar kartun dengan tujuan agar di dalam pembelajaran siswa menjadi semakin tertarik dan tidak menyebabkan kebosanan, (c) 
JPFK, Vol. 2 No. 1, Maret 2016, hal 16 - 28

http://e-journal.ikippgrimadiun.ac.id/index.php/JPFK

dilengkapi audio musik yang dapat mendukung suasana pembelajaran, (d) disediakan soal evaluasi untuk mengukur tingkat kepahaman siswa terhadap materi yang telah dipelajari.

e. Pengembangan perangkat penilaian

Perangkat penilaian ini mencakup penilaian aspek kognitif proses, kognitif produk, afektif, dan psikomotor. Pengembangan perangkat penilaian dilakukan dengan prinsip pengembangan yang dikemukakan oleh Trianto (2011). Menurutnya perangkat penilaian harus dikembangkan dengan mengacu pada kompetensi dasar yang ingin dicapai, dijabarkan ke dalam indikator pencapaian hasil belajar dan disusun berdasarkan kisi-kisi penulisan butir soal lengkap dengan kunci jawaban serta lembar observasi penilaian psikomotorik dan afektif siswa. Lembar penilaian psikomotorik dan afektif siswa, pengembangannya sesuai dengan proporsi domain afektif dan psikomotorik yang dikemukakan oleh Munthe (2012) yaitu indikator dikembangkan sesuai dengan karakteristik siswa, satuan pendidikan, dan potensi daerah.

4. Pembahasan Hasil Tahap Validasi Produk Awal dan Revisi I

Produk awal yang divalidasi oleh 9 validator mendapatkan penilaian yang "sangat baik". Hal ini disebabkan oleh ketaatan terhadap pedoman pengembangan perangkat pembelajaran yang ada. Hasil revisi menunjukan perbaikan pada hal yang bersifat teknis yaitu tata tulis dan tata bahasa. Menurut Prastowo (2012), perangkat pembelajaran atau bahan ajar yang dikembangkan sesuai dengan pedoman yang ada, baik itu dari pemerintah maupun para pakar, akan berpengaruh pada kualitas pembelajaran di kelas, sehingga sebaiknya guru benar-benar mengikuti pedoman-pedoman tersebut.

5. Pembahasan Hasil Tahap Uji Coba Produk

a. Uji Coba Terbatas dan Revisi II

1) Keterlaksanaan Pembelajaran

Hasil observasi keterlaksanaan

pembelajaran yang telah dilakukan, menunjukkan bahwa pertemuan I dan II mendapatkan penilaian yang sangat baik dari pengamat, sehingga dapat dikatakan pembelajaran yang telah dilakukan efektif, efisien, dan menarik. Suatu materi pelajaran yang disampaikan guru bisa saja menarik bagi siswa tetapi belum tentu efektif dan efisien. Pembelajaran yang diberikan di kelas terikat pada rencana pelaksanaan pembelajaran (RPP) yang disusun oleh guru. Pada RPP terdapat standar kompetensi (SK), kompetensi dasar (KD), dan indikator, sehingga dapat ditentukan metode dan media pembelajaran serta alokasi waktu yang dibutuhkan. Karena dalam pembelajaran terdapat kegiatan memilih, menetapkan, dan mengembangkan metode untuk mencapai hasil pembelajaran yang diinginkan. Pemilihan, penetapan, dan pengembangan metode ini didasarkan pada kondisi pembelajaran yang ada (Uno, 2008). Hal ini tidak sejalan dengan evaluasi pendidikan karakter di sekolah menengah oleh Nancy (2013) yaitu efek pendidikan karakter dalam program yang diterapkan di siswa Amerika adalah tidak berpengaruh secara konsisten pada perilaku siswa di situasi yang berbeda.

\section{2) Tanggapan Siswa}

Rerata tanggapan 8 siswa yang mengikuti uji coba terbatas menggunakan metode pembelajaran berbasis masalah (problem based learning) terintegrasi pendidikan karakter yang melatihkan keterampilan berfikir kritis, kreatif dan mengembangkan karakter siswa adalah "Baik". Sehingga dapat disimpulkan, penerimaan siswa terhadap pembelajaran menggunakan produk yang dikembangkan juga baik. Penerimaan siswa terhadap pembelajaran dipengaruhi oleh beberapa faktor, salah satunya adalah pemilihan metode pembelajaran yang akan digunakan oleh guru dengan mempertimbangkan beberapa faktor, salah satunya adalah karakteristik siswa dan materi yang akan diajarkan. Penyesuaian pemilihan metode dengan karakteristik siswa dan materi yang akan diajarkan, akan memudahkan proses pembelajaran, sehingga penerimaan siswa terhadap pembelajaran positif, berlangsung dengan baik, dan mencapai tujuan yang ingin dicapai pada pembelajaran tersebut (Amirin, 2012).

Menurut Uno (2008) pengetahuan guru terhadap isi mata pelajaran harus sangat baik. Hanya dengan demikian seorang guru akan mampu menemukan informasi, yang menurut Ausubel "sangat abstrak, umum, dan inklusif", yang mewadahi hal-hal yang akan diajarkan. Selain itu, logika berpikir guru juga dituntut sebaik mungkin. Tanpa memiliki logika berpikir yang baik, maka guru akan kesulitan memilah-milah materi pelajaran, merumuskannya dalam rumusan yang singkat dan padat, serta mengurutkan materi demi materi ke dalam struktur urutan yang logis dan 
JPFK, Vol. 2 No. 1, Maret 2016, hal 16 - 28

\section{http://e-journal.ikippgrimadiun.ac.id/index.php/JPFK}

mudah dipahami. Belajar, pada akhirnya, bergantung dari kondisi dua pihak. Kondisi ini menyangkut kesiapan siswa dalam menerima berbagai sumber belajar dan kesiapan sumber belajar (guru dan berbagai sumber belajar lainnya) dalam mengkonstruksikan pengetahuan siswa.

Rencana kegiatan yang tidak terlaksananya pada uji coba terbatas, menjadi bahan evaluasi agar penggunaan produk pada uji coba diperluas lebih baik lagi, sehingga pembelajaran dapat berlangsung secara optimal. Sedangkan berdasarkan hasil uji reliabilitas serta validitas, soal pretest-posttest yang akan diujikan pada uji coba diperluas sebanyak 30 soal. Hasil evaluasi ini (revisi II), menghasilkan produk Draf III yang akan digunakan pada uji coba diperluas.

\section{b. Uji Coba Diperluas dan Revisi III}

1) Keterlaksanaan Pembelajaran

Pola pembelajaran yang dinilai telah terlaksana dengan baik pada uji coba terbatas produk, menjadi dasar penggunaan produk pada uji coba diperluas. Secara umum, keterlaksanaan pembelajaran yang terjadi pada uji coba diperluas tidak berbeda dengan uji coba terbatas, perbedaannya terletak pada terlaksananya pretest pada pertemuan I dan postest pada pertemuan II.

Pembahasan berkaitan dengan karakteristik problem based learning dan uji coba diperluas pada masing-masing tahap adalah (1) pengajuan pertanyaan atau masalah dalam fase orientasi masalah, hal ini bukan berarti mengorganisasikan pada keterampilan akademik tertentu akan tetapi mengorganisasikan pengajaran di sekitar pertanyaan dan masalah yang keduanya secara sosial penting dan secara pribadi bermakna pada siswa dengan mengajukan situasi kehidupan nyata autentik, menghindari jawaban sederhana, dan memungkinkan adanya berbagai macam solusi untuk situasi tersebut. Dalam tahap ini karakter rasa ingin tahu dan gemar membca akan mendominasi untuk bisa muncul di siswa dengan mengungkapkan masalah dan jawaban secara jujur. (2) berfokus pada keterkaitan antardisiplin pada fase mengorganisasikan siswa untuk belajar, meskipun pembelajaran berbasis masalah berpusat pada mata pelajaran tertentu yaitu IPA Fisika maka siswa menyelidiki masalah benarbenar nyata dalam pemecahanya dan meninjau dari banyak mata pelajaran yang berkaitan.
Dalam Fisika disajikan permasalahan berkaitan dengan gejala alam yang sangat berhubungan dengan gejala sosial, ekonomi dan disiplin ilmu lainya. Contoh pada pembelajaran frekuensi getaran yang dihubungkan dengan frekuensi belajar maka semakin banyak frekuensi yang dilakukan maka hasilnya juga akan semakin banyak pula sehingga memacu siswa untuk belajar lebih giat. (3) penyelidikan autentik dalam fase membantu penyelidikan mandiri dan kelompok. Pembelajaran berbasis masalah mengharuskan siswa melakukan penyelidikan autentik untuk mencari penyelesaian nyata terhadap masalah dengan metode ilmiah yaitu mendefinisikan masalah, merumuskan hipotesis, mengumpulkan informasi, melakukan percobaan, menganalisis data, dan merumuskan kesimpulan. Dalam proses ini karakter ilmiah dapat muncul selama proses tersebut dijalani dengan baik yaitu jujur, rasa ingin tahu, gemar membaca, kreatif, kerja keras, dan disiplin. (4) menghasilkan produk dan mempresentasikanya dalam fase mengembangkan dan menyajikan hasil karya serta memamerkannya. Pembelajaran berdasarkan masalah menuntut siswa untuk meghasilkan produk tertentu dalam bentuk karya nyata. Produk dapat berupa laporan, model fisik, ataupun program komputer. Karya tersebut direncanakan dan dipresentasikan oleh siswa. Hal ini melatih keterampilan sosial siswa dalam keterampilan psikomotorik meyampaikan gagasan, menjelaskan sesuatu dalam berkomunikasi, pendengar aktif, menghargai pendapat orang lain, dan keterampilan mulai merangkai alat, medesain percobaan, melakukan percobaan, mengalasisis data serta merumuskan kesimpulan dam bentuk laporan. (5) kolaborasi dalam fase menganalisis dan mengevaluasi proses pemecahan masalah. Pembelajaran berbasis masalah dicirikan oleh siswa yang bekerja sama satu dengan yang lainya, paling sering secara berpasangan atau kelompok kecil bekerja sama memberikan motivasi untuk secara berkelanjutan terlibat dalam tugas-tugas kompleks dan memperbanyak peluang untuk mengembangkan keterampilan sosial dan kemampuan berfikir siswa.

2) Taggapan Siswa

Tanggapan siswa yang pada uji diperluas tidak jauh berbeda dengan pada uji coba terbatas, namun memliki rerata lebih tinggi pada Tabel 4. Hal ini menandakan ada sedikit perbaikan terhadap pembelajaran yang diterapkan pada uji coba diperluas. Perbaikan 
JPFK, Vol. 2 No. 1, Maret 2016, hal 16 - 28

\section{http://e-journal.ikippgrimadiun.ac.id/index.php/JPFK}

tersebut adalah terkait dengan cara guru untuk lebih dekat dengan siswa, menganggap siswa sebagai teman, dan mengenal lebih dalam pribadi siswa. Hal tersebut sesuai dengan pendapat Dharma (2008), bahwa sikap guru yang yang hangat, bersahabat, penuh percaya diri dan antusias, merupakan faktor penting yang akan meningkatkan partisipasi aktif siswa.

\section{3) Hasil Belajar Kognitif}

Berdasarkan kesimpulan yang telah diperoleh dari pengujian hasil belajar kognitif pada Tabel 6, bahwa terdapat perbedaan yang signifikan antara hasil belajar siswa sebelum (pretest) dan sesudah (postest), serta terdapat peningkatan rerata yaitu sebesar 42,51 untuk rerata pretest dan sebesar 63,32 untuk rerata postest, mengartikan sebuah keberhasilan dalam proses pembelajaran yang telah dilalui oleh siswa menggunakan perangkat yang telah dikembangkan. Amirin (2012), mengungkapkan bahwa keberhasilan proses pembelajaran siswa dipengaruhi oleh beberapa faktor yang salah satunya adalah metode yang digunakan oleh guru. Penggunaan metode problem based learning menurut Suherman cit Ibrahim (2000) menyatakan bahwa model PBL melatih dan mengembangkan kemampuan untuk menyelesaikan masalah yang berorientasi pada masalah yang autentik dari kehidupan aktual siswa, untuk merangsang kemampuan berpikir tingkat tinggi. Sehingga terlihat melalui posttest setelah siswa mengikuti pembelajaran problem based learning dengan baik dan menghasilkan kemampuan berfikir siswa menjadi lebih tinggi. Peran guru selama berlangsungnya proses pembelajaran juga menjadi salah satu faktor yang mempengaruhi peningkatan kemampuan kognitif siswa karena guru lebih menempatkan dirinya sebagai motivator dan fasilitator. Sejalan dengan penelitian Archaree (2007) pada siswa SMP kelas 8 di Thailand yaitu penggunaan metode problem based learning dengan modul e-learning yang diterapkan efektif dalam proses pembelajaran dengan terjadi peningkatan kemampuan ICT dan kognitif siswa.

4) Hasil Penilaian Psikomotorik

Deskripsi data hasil pencapaian psikomotorik yang disajikan pada Tabel 7 dan dianalisis pada Tabel 8 menunjukkan bahwa terjadi peningkatan pencapaian rata-rata psikomotorik dalam setiap pertemuan dan setiap aspek. Selain itu, frekuensi pencapaian psikomotorik terbanyak siswa, berada pada pencapaian (kategori) "Berhasil". Sehingga secara hasil umum penggunaan perangkat pembelajaran berhasil mengembangkan keterampilan psikomotor siswa.

Aspek pencapaian indikator psikomotor tertinggi adalah aspek mengecek alat bahan dan membawa perlengkapan belajar sedangkan aspek paling rendah adalah keterampilan menjelaskan kembali. Hal ini menunjukan bahwa siswa mempunyai ketertarikan dalam mengembangkan keterampilan psikmotorik. Siswa mampu mengecek alat dan bahan yang terdapat di laboratorium bahkan siswa mencari sendiri alat dan bahan yang tidak terdapat di laboratorium sekolah. Keterampilan paling rendah adalah kemampuan menjelaskan kembali yang berkaitan dengan mengkomunikasikan yang diperoleh siswa. Keterampilan ini masing belum bisa muncul di setiap siswa karena berkaitan dengan keberanian siswa dan kemampuan siswa setelah belajar.

Sejalan dengan penelitian Ronteltap
(2002) tentang kolaborasi perangkat
pembelajaran yang diimplementasikan pada
pembelajaran berbasis masalah. Hasilnya
adalah siswa yang berdiskusi memiliki
keberanian mengungkapkan pendapat serta
berpengaruh signifikan terhadap prestasi
belajarnya.

\section{Keterbatasan Penelitian}

Keterbatasan penelitian dan pengembangan ini yaitu: (1) pelaksanaan tahap pengembangan perangkat pembelajaran IPA Fisika SMP berbasis problem based learning terintegrasi pendidikan karakter pada penelitian ini dilaksanakan dengan menerapkan metode Research and Development oleh Borg \& Gall, yakni langkah 1-7, namun langkah 8-10 tidak dilaksanakan karena keterbatasan sumber daya, (2) keterbatasan waktu yang pada saat tempat uji coba, (3) penilaian terhadap psikomotorik dan karakter siswa hanya dilakukan oleh guru dengan metode pengamatan (observasi), (4) media ajar animasi flash yang terlalu banyak gambar kartun sehingga memecah konsentrasi siswa dalam menggunakan media ajar tersebut, (5) perangkat pembelajaran belum sepenuhnya memerapkan subject spesifik terutama pada rencana pelaksanaan pembelajaran (RPP), (5) dalam penelitian tidak dilakukan ujicoba eksperimen pada kelas kontrol dan uji coba (try 
JPFK, Vol. 2 No. 1, Maret 2016, hal 16 - 28

\section{http://e-journal.ikippgrimadiun.ac.id/index.php/JPFK}

out) untuk mengetahui validitas soal yang

digunakan sebagai tes hasil belajar siswa.

\section{Kesimpulan dan Rekomendasi}

\section{Kesimpulan}

Berdasarkan hasil analisis data dan pembahasan yang telah dilakukan dapat disimpulkan: (1) pengembangan perangkat pembelajaran IPA Fisika SMP berbasis problem based learning terintegrasi pendidikan karakter dilakukan menggunakan metode Research and Development oleh Borg \& Gall yang dimodifikasi dengan membatasi langkah penelitian yang dapat menghasilkan suatu produk yang divalidasi dan diuji coba, (2) kualitas produk perangkat pembelajaran yang dikembangkan melalui serangkaian uji validitas oleh validator ahli, guru, dan tema sejawat dilanjutkan uji coba terbatas dan uji coba diperluas meliputi uji keterlaksanaan pembelajaran, respons siswa, dan uji coba tes hasil belajar mendapatkan nilai dengan kategori sangat baik sehingga perangkat pembelajaran yang dikembangkan layak digunakan, (3) pencapaian hasil belajar secara kognitif siswa setelah mengikuti proses pembelajaran menggunakan produk perangkat pembelajaran yang dikembangkan mengalami peningkatan dari kondisi awal sampai pada kondisi akhir pada aspek kognitif, pada aspek indikator psikomotor tertinggi adalah mengecek alat bahan di laboratorium dan membawa perlengkapan belajar.

\section{Daftar Rujukan}

Amirin, Siti. (2012). Pembelajaran Biologi Model Children's Learning in Science Melalui Inkuiri Terbimbing dan Inkuiri Bebas Termodifikasi Ditinjau dari Sikap Ilmiah dan Kemampuan Berpikir Kritis. Tesis. UNS. (Unpublished).

Archaree, Pummawan. (2007). The Development Of An E-Learning Module On The Sandy Shores Ecosystem For Grade 8 Secondary Student. Educational Jurnal Of Thailand. 1 (1): 95-110.

Carol C. K., dan Leslie K.M. (2010). Building Guided Inquiry Terms for 21st-
Century Learners. School Library Monthly. 26 (5): 18-28.

Depdiknas. (2006). Pedoman Memilih dan Menyusun Bahan Ajar. Jakarta: Direktorat Jenderal Manajemen Pendidikan Dasar dan Menengah.

Depdiknas. (2006). Peraturan Menteri Pendidikan Nomor 22 Tahun 2006 Tentang Standar Isi untuk Satuan Pendidikan Dasar dan Menengah. Jakarta: Departemen Pendidikan Nasional

Depdiknas. (2007). Materi Sosialisasi dan Pelatihan Kurikulum Tingkat Satuan Pendidikan (KTSP) SMK. Jakarta: Depdiknas.

Dharma, Surya. (2008). Monitoring dan Evaluasi Pelaksanaan Pembelajaran. Jakarta: Ditjen PMPTK. (Unpublished).

Fauzi, Ahmad. (2009). Pengembangan Bahan Ajar Fisika dengan Aplikasi Spreadsheet. Thesis. Semarang: Universitas Negeri Semarang.

Gall, Borg (2007). Research Development. Boston: Allyn \& Bacon.

Gerthsen, M.D. dan Borg, W.R. (2003). Educational Research An Introduction 7th Edition. Boston: Allyn \& Bacon.

Ibrahim, M., dan Nur, M. (2000). Pengajaran Berdasarkan Masalah. Surabaya: University Press.

Kemendiknas. (2010). Bahan Pelatihan: Penguatan Metodologi Pembelajaran Berdasarkan Nilainilai Budaya Untuk Membentuk Daya Saing dan Karakter Bangsa. Jakarta: Kemendiknas RI.

Kesuma, Dharma (2011). Pendidikan Karakter: Kajian Teori dan Praktik di Sekolah. Bandung: Rosda Karya.

Mulyasa, Enco. (2007). Kurikulum Tingkat Satuan Pendidikan: Suatu Panduan 
Praktis. Bandung: PT. Remaja Rosdakarya.

Munthe, Bermawi. (2012). Desain Pembelajaran. Yogyakarta: Insan Madani.

Permendiknas. (2007). Standar Proses untuk Satuan Pendidikan Dasar dan Menengah. Jakarta: BSNP.

Prastowo, Andi. (2012). Panduan Kreatif Membuat Bahan ajar Inovatif. Yogyakarta: Diva Press.

Ronteltap et al. 2002. Activity and Interaction of Students in an Electronic Learning Environment for Problem-Based Learning. Journal of Distance Education. 23 (4): 11-22. Kemdiknas.

$$
\text { (2010). Peraturan }
$$

Pemerintah Republik Indonesia Nomor 17 Tahun 2010 Tentang Pengelolaan dan Penyelenggaraan Pendidikan. Jakarta: Kemdiknas.

Suwarna. (2011). Panduan Pengajaran Mikro. Yogyakarta: UNY Press.

Trianto. (2011). Mendesain Model Pembelajaran Inovatif-Progresif: Konsep, Landasan, dan Implementasinya Pada Kurikulum Tingkat Satuan Pendidikan (KTSP). Jakarta: Kencana.

Uno, Hamzah B. dan Nurdin Mohamad. (2012). Belajar dengan Pendekatan PAILKEM: Pembelajaran Aktif, Inovatif, Lingkungan, Kreatif, Efektif, dan Menarik. Jakarta: Bumi Aksara. 